\title{
Associations Diabetes Knowledge and Glycemic Control among Diabetes Mellitus Patients in Garut District, Indonesia
}

\author{
Iin Patimah*, Sri Yekti Widadi, Muhamad Arid Riyadi \\ Department of Medical Surgical Nursing, Sekolah Tinggi Ilmu Kesehatan Karsa Husada Garut Indonesia \\ *Corresponding Author \\ Iin Patimah
}

\section{Article History}

Received: 18.12 .2020

Accepted: 31.12 .2020

Published: 06.01.2021

\begin{abstract}
Introduction: Diabetes mellitus is a non-communicable disease with a high incidence in various countries, including Indonesia. Poor levels of sugar control are the cause of complications of diabetes mellitus. Diabetes knowledge is one of the keys to assist in controlling blood sugar levels in diabetes mellitus patients. Objective: This research assesses the associations between diabetes knowledge and glycemic control among diabetes mellitus patients in Garut District, Indonesia. Methode: The research method was designed using a cross-sectional with a number of sample 54 responded. data take with structured self-report interviews based on validated instruments for assessing diabetes knowledge and observation sheet to monitor blood sugar levels to assess glycemic control. The diabetes knowledge instrument contains questions about the concept of diabetes and management of diabetes in general. Glycemic control was measured by the value of blood sugar once a week for 4 weeks. Chi-Square statistical test was used to analyze the data. Results: The research findings that 19 respondents had good knowledge and controlled blood sugar levels. 35 respondents with insufficient knowledge where 31 respondents had uncontrolled blood sugar levels and 4 respondents had controlled blood sugar levels. Chi-Square test finds a significant probability $(\mathrm{p}=0.000)$, there was a relationship between diabetes knowledge and Glycemic control. Conclusion: Diabetes knowledge is the important factors associated with glycemic control. Education for patients diabetes mellitus are suggested to improve control glycemic diabetes patient.
\end{abstract}

Keywords: Blood Sugar, Control, Glycemic, Diabetes Mellitus, Knowledge.

\section{INTRODUCTION}

Diabetes mellitus is a group of metabolic diseases characterized hyperglycemia, abnormalities metabolic in carbohydrates, proteins and lipids resulting from impaired insulin secretion, impaired insulin work or both [1]. In Indonesia, prevalence of diabetes mellitus has increased by $1.6 \%$ in 2018. Based on the examination of blood sugar levels that have been carried out, diabetes mellitus has increased from $6.9 \%$ to $8.5 \%$ [2]. Prevalence of diabetes mellitus is worrying, in the long term diabetes mellitus will become increasingly high, with the increasing incidence of diabetes mellitus, it will result in the risk of developing other diseases as complications of diabetes mellitus such as: neuropathy, nephropathy, stroke, cardiovascular disease, peripheral artery disease (PAD), diabetic foot syndrome, dental disease, reduced resistance to infections, and birth complications among women with gestational diabetes, finally can impact on increasing morbidity and mortality [3-5].

One way to prevent complications of diabetes mellitus is that each patient must be able to control blood sugar levels in his body by carrying out a healthy lifestyle such as adjusting diet and daily physical activity patterns [6, 7]. To be able to control blood sugar levels, diabetics patient must have good knowledge about diabetes mellitus coupled with high motivation to curiosity about diabetes mellitus and supported by the role of health workers to regularly carry out counseling aimed at increasing patient knowledge about diabetes mellitus. and how to control blood sugar levels [8]. Diabetes mellitus is a chronic disease that is categorized as dangerous, so controlling blood sugar levels is an effective way to manage diabetes mellitus in the long term. Control of blood sugar levels includes meal planning, physical exercise, education, and analgesic drugs according to a doctor's prescription [9].

Copyright (C) 2021 The Author(s): This is an open-access article distributed under the terms of the Creative Commons Attribution 4.0 International License (CC BY-NC 4.0) which permits unrestricted use, distribution, and reproduction in any medium for non-commercial use provided the original author and source are credited. 


\section{METHOD}

The research design used in this study was a correlation analysis using a cross sectional approach. The independent variable in this study is knowledge about diabetes mellitus (DM) and the dependent variable in this study is the control of blood sugar levels in people with diabetes mellitus (DM). The population in this study were all patients suffering from diabetes mellitus in the Guntur Health Center, Garut Regency. The sampling technique in this study was to use purposive sampling with a total sample of 54 respondents. Research tools in the form of a questionnaire regarding knowledge of diabetes mellitus (DM) and medical record records for 4 weeks of diabetes mellitus sufferers at Guntur Health Center, Garut Regency. data take with structured self-report interviews based on validated instruments for assessing diabetes knowledge and observation sheet to monitor blood sugar levels to assess glycemic control. The diabetes knowledge instrument contains questions about the concept of diabetes and management of diabetes in general. Glycemic control was measured by the value of blood sugar once a week for 4 weeks. The data analyzed using univariate analysis were knowledge about diabetes mellitus (DM) and controlling blood sugar levels, then the data were tabulated, bivariate analysis was carried out on the two variables by means of the chi square test, namely the "Rank Spearman" correlation to see the relationship. between the independent variable and the dependent variable.

\section{RESULT}

Table-1: Frequency Distribution of DM Patients Based on Characteristics In the Guntur Health Center, Garut Regency

\begin{tabular}{|l|l|l|l|}
\hline No. & Characteristics & F & $\%$ \\
\hline 1. & Sex & & \\
& - Women & 33 & 61,1 \\
& - man & 21 & 38,9 \\
& Total & 54 & 100 \\
\hline 2. & Age & & \\
& $-<=50$ & 27 & 50 \\
& $->50$ & 27 & 50 \\
& Total & 54 & 100 \\
\hline 3. & Level Education & & \\
& - Elementary School & 24 & 44,5 \\
& - junior High School & 18 & 33,3 \\
& - High School & 12 & 22,2 \\
& Total & 54 & 100 \\
\hline 4. & Employment & & \\
& - unemployed & 26 & 48,1 \\
& - self-employed & 15 & 27,8 \\
& - laborer & 9 & 16,7 \\
& - civil servant & 4 & 7,4 \\
& Total & 54 & 100 \\
\hline
\end{tabular}

Based on the results of data processing, the frequency distribution of respondents with Diabetes Mellitus in the Guntur Health Center, Garut Regency on the characteristics sex known that most of the respondents $(61.1 \%)$ are female. Then the age characteristics show that some respondents $(50 \%)$ are $<=50$ years old, and some respondents $(50 \%)$ are $>50$ years old. Then on the educational characteristics it is known that some respondents $(44.5 \%)$ have an elementary school. Meanwhile, on the job characteristics, it is known that some respondents $(48.1 \%)$ unemployed

Table-2: Results of the Analysis of the Relationship between Knowledge of Diabetes Mellitus and Control of Blood Sugar Levels in Diabetes Mellitus Patients in the Guntur Health Center, Garut Regency

\begin{tabular}{|c|c|c|c|c|c|c|c|c|c|}
\hline \multirow[t]{3}{*}{ Diabetes Knowledge } & \multicolumn{4}{|c|}{ Control Blood Sugar } & \multirow{2}{*}{\multicolumn{2}{|c|}{ Total }} & \multirow[t]{3}{*}{ P.Value } & \multirow[t]{3}{*}{$\alpha$} & \multirow[t]{3}{*}{$\mathbf{r}$} \\
\hline & \multicolumn{2}{|c|}{ Good control } & \multicolumn{2}{|c|}{ Bad control } & & & & & \\
\hline & $\mathbf{F}$ & $\%$ & $\mathbf{F}$ & $\%$ & $\mathbf{F}$ & $\%$ & & & \\
\hline Good & 19 & 35,2 & 0 & $0 \%$ & 19 & 35,2 & 0,000 & 0,01 & 0,855 \\
\hline Less & 4 & 7,4 & 31 & 57,4 & 35 & 64,8 & & & \\
\hline Total & 23 & 42,6 & 31 & 57,4 & 54 & 100 & & & \\
\hline
\end{tabular}

Based on data processing regarding the Relationship between Knowledge about DM and Control of Blood Sugar Levels in DM Patients in the Guntur Garut Health Center in 2019, it shows that most respondents (57.4\%) who have less knowledge, their blood sugar levels are not controlled. Meanwhile, a small proportion of respondents $(35.2 \%)$ who had good knowledge had controlled blood sugar levels. Very few of the respondents (7.4\%) had less knowledge but 
controlled blood sugar levels, it was caused by several other factors such as routinely calling the Guntur Health Center nurse every 1 week to monitor and guide the DM sufferer.

Based on the results of data processing correlation analysis regarding the Relationship of Knowledge About Diabetes Mellitus to Control of Blood Sugar Levels in Diabetes Mellitus Patients in the Guntur Health Center, Garut Regency, the bivariate test results obtained p-value $=0.000<0.01$ which means that Ho is rejected and Ha is accepted, with Thus it can be concluded that there is a relationship between knowledge about DM on controlling blood sugar levels in DM patients in the Guntur Health Center, Garut Regency in 2019. While the value for the degree of error in the results of bivariate data processing regarding the Relationship between Knowledge about Diabetes Mellitus and Control of Blood Sugar Levels in Patients Diabetes mellitus in the area of Guntur Health Center, Garut Regency is determined based on the formula Dahlan [10], namely 0.01. For the results of the correlation coefficient of data processing, correlation analysis is based on the significance value of sig. (2-tailed) the sig value is known. (2-tailed) between knowledge of DM $(\mathrm{X})$ on controlling blood sugar levels $(\mathrm{Y})$ is $0.000<0.01$, which means that there is a significant correlation between knowledge of DM on controlling blood sugar levels. And based on the calculated r value (pearson correlations), it is known that the value of $r$ calculated for the relationship of knowledge about DM (X) to controlling blood sugar levels $(\mathrm{Y})$ is $0.855>0.537$. By obtaining the results of the correlation coefficient, it can be concluded that there is a relationship between knowledge of DM and controlling blood sugar levels because the value of 0.855 is a very strong relationship category.

\section{DISCUSSION}

Knowledge of DM is one of the important factors that affect controlling blood sugar levels of a person affected by DM. The quality of a person's knowledge about DM which can affect controlling blood sugar levels is influenced by several factors, namely educational factors, because if a person takes a higher level of education it can add broad experience and insight level of education was correlated with habit at the community, for example joining meetings, educating of the family and/or close related person. Furthermore, high school level education more often thought they had the skill to take behaviour of control and that their recomendations were learned [11].

Furthermore, the work factor explains that a person's job will affect one's knowledge when one's job uses the brain more often than the muscles [12]. The performance and ability of a person's brain to store (memory) will increase if used frequently, this is inversely proportional to someone whose job uses muscles more often. Then the age factor, because age can affect a person's perception and mindset. As you get older, your perception and mindset will also develop. At the age of 20-39 years, individuals will be more active in society and social life and have more time to read. In contrast to people aged 40 years and over the ability to remember and think patterns tend to have decreased due to decreased organ function decline over time. Then the motivational factor because if someone has high motivation to curiosity about something, then someone will try to find information about the things he wants to know.

With the knowledge about DM that is owned, it will change the attitude and mindset of the DM sufferer towards controlling their blood sugar levels. But the attitude and mindset of the sufferer can be positive or negative which is caused by several external factors, the first is motivation. For example, a DM sufferer has good knowledge of DM and has controlled blood sugar levels because of high motivation to be able to control his blood sugar levels. So from this motivation arises behavior to control blood sugar levels by adopting a healthy lifestyle such as maintaining a balanced diet and nutritional intake, especially carbohydrate and sugar intake. And another example, for example a DM sufferer has good knowledge but does not have high motivation to control blood sugar levels so that this person arises negative attitudes and thinking patterns and does not care about their blood sugar levels. So that there are unhealthy lifestyle behaviors such as diet and nutritional intake that are irregular or at will and tend to be lazy to do physical activities or exercise. The second is the factor of health workers. With routine health workers, especially Puskesmas nurses, conducting health education activities, it will increase knowledge and insight and motivate DM sufferers which can have a positive impact on controlling blood sugar levels. Third, namely environmental factors, because if someone lives in an environment where the average population has good knowledge of DM, then indirectly that person will be exposed to information about DM so that they will know how to control blood sugar levels. The fourth is family encouragement, because if a DM sufferer has good knowledge of DM and knows how to control blood sugar levels but does not want to have a healthy lifestyle, that is where the role of the family is needed to be able to provide support to DM sufferers to immediately change their lifestyle for the sake of the health of the DM sufferer [13].

\section{CONCLUSSION}

A small proportion of respondents have a good level of knowledge and always try to keep their blood sugar levels under control. Meanwhile, more than half of the respondents had a low level of knowledge and could not keep their blood sugar levels under control. There is a significant relationship between knowledge of DM on controlling blood sugar levels in DM patients in the Guntur Health Center, Garut Regency. From the results of this study, it is hoped that 
health workers, especially nurses, can guide and provide education to DM sufferers about DM by using the right methods or media in order to get maximum results.

\section{ACKNOWLEDGEMENTS}

The author would like to thank all those who have contributed to this research: the Head of the Guntur Health Center, Garut Regency, the head of STIKes Karsa Husada Garut, all respondents who were involved in this research as well as all parties that the author could not mention one by one.

\section{REFERENCES}

1. Kharroubi, A. T., \& Darwish, H. M. (2015). Diabetes mellitus: The epidemic of the century. World Journal of Diabetes, 6(6), 850-867. https://doi.org/10.4239/wjd.v6.i6.850

2. Kesehatan, B. penelitian dan pengembangan. (2013). Riset Kesehatan dasar. http://www.depkes.go.id/resources/download/general/Hasil Riskesdas 2013.pdf

3. Deshpande, A. D., Harris-Hayes, M., \& Schootman, M. (2008). Epidemiology of diabetes and diabetes-related complications. Physical Therapy, 88(11), 1254-1264. https://doi.org/10.2522/ptj.20080020

4. Tuttolomondo, A., Maida, C., \& Pinto, A. (2015). Diabetic foot syndrome as a possible cardiovascular marker in diabetic patients. Journal of Diabetes Research, 2015, 268390. https://doi.org/10.1155/2015/268390

5. Papatheodorou, K., Banach, M., Bekiari, E., Rizzo, M., \& Edmonds, M. (2018). Complications of Diabetes 2017. Journal of Diabetes Research, 2018, 3086167. https://doi.org/10.1155/2018/3086167

6. Sami, W., Ansari, T., Butt, N. S., \& Hamid, M. R. A. (2017). Effect of diet on type 2 diabetes mellitus: A review. International Journal of Health Sciences, 11(2), 65-71. https://pubmed.ncbi.nlm.nih.gov/28539866

7. Asif, M. (2014). The prevention and control the type-2 diabetes by changing lifestyle and dietary pattern. Journal of Education and Health Promotion, 3, 1. https://doi.org/10.4103/2277-9531.127541

8. Bukhsh, A., Khan, T. M., Sarfraz Nawaz, M., Sajjad Ahmed, H., Chan, K. G., \& Goh, B.-H. (2019). Association of diabetes knowledge with glycemic control and self-care practices among Pakistani people with type 2 diabetes mellitus. Diabetes, Metabolic Syndrome and Obesity: Targets and Therapy, 12, 1409-1417. https://doi.org/10.2147/DMSO.S209711

9. Johnson, E. L., Feldman, H., Butts, A., Chamberlain, J., Collins, B., Doyle-Delgado, K., Dugan, J., Leal, S., Rhinehart, A. S., Shubrook, J. H., \& Trujillo, J. (2020). Standards of medical care in diabetes-2020 abridged for primary care providers. Clinical Diabetes, 38(1):10-38. https://doi.org/10.2337/cd20-as01

10. Dahlan, N. D., Jones, P. J., Alexander, D. K., Salleh, E., \& Dixon, D. (2008). Field measurement and subjects' votes assessment on thermal comfort in high-rise hostels in Malaysia. Indoor and Built Environment, 17(4), 334-345.

11. Diaz-Quijano, F. A., Martínez-Vega, R. A., Rodriguez-Morales, A. J., Rojas-Calero, R. A., Luna-González, M. L., \& Díaz-Quijano, R. G. (2018). Association between the level of education and knowledge, attitudes and practices regarding dengue in the Caribbean region of Colombia. BMC Public Health, 18(1):143. https://doi.org/10.1186/s12889-018-5055-Z

12. Pangesti, C. B., \& Agussafutri, W. D. (2019). The Relationship Between Mother's Occupational Status And Knowledge About Posyandu Balita With Compliance Of Visiting Posyandu At Posyandu Balita Singosari Kelurahan Banyuanyar Surakarta. Jurnal Kebidanan Indonesia, 10(2), 32-40.

13. Suwaryo, P. A. (2017). Faktor-Faktor Yang Mempengaruhi Tingkat Pengetahuan Masyarakat dalam Mitigasi Bencana Alam Tanah Longsor. Magelang: Urecol.

Citation: Iin Patimah et al (2021). Associations Diabetes Knowledge and Glycemic Control Among Diabetes Mellitus Patients in Garut District, Indonesia. South Asian Res J Nurs Health Care, 3(1), 1-4. 